\title{
The Effect of Leadership Style, Competence and Motivation on Employee Performance Dinas Pengelolaan Bangunan and Tanah Kota Surabaya
}

\author{
Hany Rifky Eryanto, Elok Damayanti \\ Faculty of Economics and Business, Narotama University \\ Jl. Arief Rahman Hakim 51 Surabaya, Indonesia 601171 \\ rifkyerryanto@gmail.com, elok.damayanti@narotama.ac.id
}

\begin{abstract}
This study aims to analyze the influence of leadership style (X1), competence (X2) and motivation (X3) on employee performance (Y) at Dinas Pengelolaan Bangunan dan Tanah Kota. The sample was obtained by random sampling method with 100 respondents from 132 employees. The data analysis used in this research includes data quality test, classical assumption test, multiple linear regression analysis, and hypothesis testing. The results of the partial significance test (t statistical test) from the analysis and discussion of the research show that leadership style, competence and motivation partially have a significant effect on employee performance and the simultaneous significance test (f test) of the analysis and discussion of the study shows that leadership style, competence and motivation together have a significant effect on employee performance at Dinas Pengelolaan Bangunan dan Tanah Kota Surabaya.
\end{abstract}

Keywords :

Competence, Leadership Style, Motivation, and Performanc.

\section{Introduction}

The bureaucratic reform agenda is a policy that requires a significant change to the elements of the organizational institutions. Changes in these elements include institutions, apparatus resources (employees), management, management, supervision, and service to the public. The reform agenda is based on the Regional Regulation Law Number 32 of 2004 which essentially gives full authority to organizational institutions to manage and manage their households and is supported by Presidential Instruction of the Republic of Indonesia Number 7 of 1999 concerning the accountability of the performance of government agencies. Responding to this agenda certainly has a goal, namely to position and prepare (Organizational Institutions) to adapt to the complex dynamics of this era, to achieve solid and responsible development, and to achieve organizational goals. In line with the principles contained in the underlying Law.

Organizational institutions at all levels of government are required to be more adaptive and anticipatory to various kinds of changes, both those that will and are happening. However, the low performance of Organizational Institutions has an impact on placing the order of Indonesia's competitiveness. According to The Global Competitiveness Report 2017-2019 (world economic forum), Indonesia is ranked 37th out of 140 countries. Thus, it demands the role of all apparatus (employees) in the organization to always hone their competencies. The role of employees in moving government institutions is of course very vital and strategic. Law Number 5 of 2014 concerning Government Organization Employees requires the implementation of Performance as the main basis and parameter for the operation of the Organizational Institution. Meanwhile, in terms of management,

The condition of the average quality of professionalism possessed by an organizational institution can be said to be not satisfactory, the cause is the ineffective practice of human resource management policies. Human Resources are the main determining factor in any organization because Human Resources can drive other existing resources. Including in the case of organizational institutions represented by human resources as bureaucrats (employees). Employees are one of the elements of strength for organizational institutions and even the main determinants, therefore employees must have high work competence and motivation to achieve goals.

Dinas Pengelolaan Bangunan dan Tanah Kota Surabaya has a work unit, one of which is the Personnel Department, with a vision of realizing quality Human Resources and professional personnel management. As one of the Government Agencies in the City of Surabaya, the Office of Building and Land Management carries out functions following the Regulation of the Mayor of Surabaya Number 57 of 2016 concerning Position, Organizational Structure, Job Descriptions, and Functions as well as Work Order which has a function or objective of City Asset Management and Public Services to the Community. The determination of the main 
tasks of the agency's functions can run if there are human resources who are professional, competent, and have the motivation to compete in carrying out their duties. Relation to Competence and Motivation,

Every organization expects to have employees with the best performance. It can be interpreted in other words, if the employee's performance is good, it will have a good impact on the organization as well. The best employee performance will make it easier for each organization to achieve its goals. An organization's success in realizing the achievement of goals is greatly influenced by the performance of its employees. This is because performance is a description of the level of achievement of an activity program or policy in realizing the goals, objectives, vision, and mission of the organization as outlined in the strategic planning of an organization (Moeheriono, 2014: 95). Performance can be influenced by internal factors, such as employee performance which affects service quality. Unfulfilled needs want and hopes, as well as a work environment that is not good enough, can weaken employee work motivation which results in weak employee performance. Human resources play a very important role, human resources are seen as the main driving factor in determining the success of a company. Boosting employee motivation must be done to encourage the achievement of good performance. (Harry Murti Veronika Agustini Srimulyani 2013).

This opinion implies that optimal employee performance is a prerequisite that must be met by the organization. Furthermore, optimal employee performance will be realized if the leadership can carry out their Leadership Style effectively. Either explore the potential or motivate its members. Leadership style is a method used by a leader in influencing the behavior of others. Leadership is an indicator of the quality of human resources that will determine the success of an organization (Rahim, Junaid, and Afa 2016). From the explanation above, it shows that Leadership Style is the main key in determining the development of employees and their organizations.

"Based on observations at the Dinas Pengelolaan Bangunan dan Tanah Kota Surabaya, we have conducted closed interviews with several employees. The results of interview observations obtained facts related to the research variables which will be discussed in this study. The results of the pre-research on respondents from the Dinas Pengelolaan Bangunan dan Tanah Kota Surabaya indicated that there were respondents who had no interest in the leadership style applied by their leaders. Because the leader in carrying out his leadership is too demanding of obedience and does not consider input from its members, it seems more rigid. Leaders with the applied leadership style have not been able to maximize the potential in their organization with applicable procedural compliance so that they do not improvise policies to tolerate input from members, emergencies, or incidents. Leaders only stick to the existing rules. Leaders do not understand that there are differences in characteristics, such as abilities, knowledge, and behavioral attitudes, resulting in solving problems between the leader and its members. (Source of an interview with the leaders/managers of the Surabaya City Government building, 2020). " Leaders do not understand the differences in characteristics, such as abilities, knowledge, and behavioral attitudes, causing solving problems between the leader and its members. " Leaders do not understand that there are differences in characteristics, such as abilities, knowledge, and behavioral attitudes, resulting in solving problems between the leader and its members. (Handoyo et al. 2020).

In a good organizational institution, it is hoped that the official (leadership) can act as a leader (leader) who is obliged to impose mentoring or training to each employee, Rukmana (in Articleong: 118). By Government Regulation Number 102 of 2000 that training/coaching aims to achieve leadership requirements to achieve good organizational performance. Leadership is the way a leader influences the behavior of subordinates so that they are willing to work together and work productively to achieve organizational goals (Hasibuan 2017). Then, according to the clause of (Pasolong 2008) Leaders are required to take part in some training series, by following the training the Leader (leader) can carry out leadership functions with all the philosophy, skills and attitudes, not necessarily only the leader who holds the position.

Competence is said to be one of the factors that affect performance. Competence is a characteristic that is fundamental to someone related to the effectiveness of individual performance in carrying out their work or basic characteristics of individuals who have a close relationship or as a cause and effect with criteria that are used as references, effectiveness, or top performance in the place where they work. (Moeheriono 2014). This is intertwined with opinion (Priansa 2017) Job competence is the capacity of employees for job attributes, which are a collection of abilities, skills, maturity, experience, effectiveness, efficiency, and success in carrying out job responsibilities. Competencies at the executive level are strategic thinking and change leadership management. At the manager level, competence includes aspects of flexibility, change implementation, interpersonal understanding, and empowering information. At the employee level, competencies such as flexibility, motivation, collaboration, and customer service are required.

The above opinion indicates that competence is important because it is a determining factor in human resources in achieving performance. Performance is the translation of performance which means the implementation of work, or work achievement (Rahadi 2010). If you want to improve your performance, you should have the appropriate competence (the right man on the right job). So the management of human resources must be managed as much as possible to achieve goals and objectives through optimal resources (Moeheriono 2014). 
"In terms of optimizing and good performance efficiency, the employees Performance Dinas Pengelolaan Bangunan dan Tanah Kota Surabaya must pay attention to the competencies possessed by each individual. The existing phenomenon is that there is still a gap between the competence held and the position. This is because there are still indications of a lack of confidence and creativity in making decisions. The educational background that is not following their position and employees who have worked for decades are not rotated according to their competencies (Handoyo et al. 2020). Based on the results of observations with the interview method, it is found that there are employees who occupy their positions do not match their educational background. Generally, formal education at the Dinas Pengelolaan Bangunan dan Tanah Kota Surabaya has high school education. (Sedarmayanti 2013) says an instrument training program to achieve the competencies required by a position to facilitate carrying out the main duties of an agency. Training that is intended is coaching by providing capital or provisions that are useful for increasing his or her abilities so that it is expected to produce high productivity. However, not all of them have received this guidance, so encouragement from the leadership is needed to improve employee competence.

Motivation becomes a motivator for someone to do an activity to get the best results. Motivation is an important thing to pay attention to if you want all goals to be achieved. The organization always wants every employee to make a positive contribution to the achievement of the goals of the organization's institution. There is a phenomenon of a decrease in work motivation in the Surabaya City Building and Land Management Service Employees. This phenomenon can be seen when doing his job. Lack of motivation causes employees to be slow at work and not responsive when there is work that must be completed quickly. This was also expressed during pre-research observations by interviewing one of the employees. The employee states that the work is carried out only as a matter of self-burden, the work is carried out only as a form of compulsion, and work is only lived as a form of routine only. It can be seen that the lack of morale of some employees in carrying out their work, the lack of willingness of some employees to improve the quality of their performance and work performance, and a lack of personal motivation to develop themselves and adjust to developments outside the organization itself.

"This condition is generally caused by a typical monotonous job and the low contribution of the leader in encouraging or encouraging work. (Dinas et al. 2016).

Starting from the problems that arise in the Dinas Pengelolaan Bangunan dan Tanah Kota Surabaya, efforts must be made so that all of these can be resolved properly so that efforts are needed such as generating positive motivation as encouragement for each employee, effective human resource management policies. , provide training / mentoring to improve employee competence, develop innovative and leadership factors that can guide employees well to create good self-motivation.

Based on the phenomena described above, it is our interest as researchers to compile a Final Thesis with the title "The Influence of Leadership Style, Competence and Motivation on Employee Performance of Dinas Pengelolaan Bangunan and Tanah Kota Surabaya".

\section{Literature Review}

\subsection{Leadership Style}

A leader who carries out his leadership functions with all his philosophy, skills, and attitudes, as a whole is perceived by employees as a leadership style. According to Harbani (2013) leadership style is a method used by a leader in influencing, directing, encouraging, and controlling his subordinates to achieve organizational goals efficiently and effectively. According to Umam (2010) leadership style is a behavior norm used by someone when that person tries to influence the behavior of others as he sees it.

According to research (basis van Hersey and Management 1996) in Hadari (2014) defines leadership style as follows "The leadership style of an individual is the behavior pattern that a person exhibits web attempting to influence the activities of others as perceived by those others. This may be very different from the leader's perception of leadership behavior, which we shall define as self-perception; rather than style "

Meanwhile, according to Moeheriono (2014)defines leadership style as a manifestation of the behavior of a leader, which concerns his ability to lead. The embodiment usually forms a certain pattern or shape. In line with the above opinion according to Hadari (2014) leadership style as a pattern of leader behavior in influencing the attitudes of behavior and so on his followers. Understanding behavior patterns are not in a static sense but a dynamic sense.

\subsection{Competence}

According to Spencer (1993) "A competency is an underlying characteristic of an individual that is causally related to the criteria referenced effective and or superior performance in a job or situation". Spencer's opinion has a definition, competence is a characteristic that underlies a person about the effectiveness of individual performance in their work or basic characteristics of individuals who have a causal relationship or as a cause-and-effect with criteria that are used as a reference, are effective, or perform prime or superior in the 
workplace or at work. certain situation. Then competence is a basic characteristic of a person that indicates how to think, behave, and act and draw conclusions that can be done and maintained by a person at a certain time.

Meanwhile, Moeheriono (2014) competence as a basic characteristic of personnel which is a determining factor for a person's success or failure in doing a job or in a certain situation Skills and knowledge have an important role in one's success, but four other competencies play a much bigger role. This is especially true in jobs that are more strategic and higher up in the hierarchy of the organization (Veithzal RivaiVeithzal Rivai 2013).

\subsection{Motivation}

Motivation is the desire to do something and determines the ability to act to satisfy individual needs. To fulfill the necessities of life one has to work. This need can be in the form of an economic need, namely to obtain money. Meanwhile, non-economic needs can be interpreted as a need to obtain appreciation and a desire to be more advanced. With all these needs, a person is required to be more active at work. To achieve this, motivation to work is required. The greater the motivation of a person, the performance will increase. To achieve organizational goals that have been set by an organization, employees often need the motivation to achieve these goals.

According to Hamdu and Agustina (2011) "Motivation is one of the several things which determine the success of the student learning activity. Without motivation, the learning process is difficult to achieve optimum success. The use of the principle of motivation is something essential in the learning and education process ". Motivation is a suggestion or encouragement that arises because someone gives it to others or oneself. The urge is intended to make the person a better person than before.

\subsection{Employee performance}

The term performance comes from the word job performance or actual performance (actual work performance or achievement achieved by a person), namely the quality and quantity of work achieved by an employee in carrying out his duties following the responsibilities assigned to him Mangkunegara (2014).

According to Wirawan (2012) performance is the output produced by functions or indicators of a job or a profession within a certain time. According to Moeheriono (2014) opinion, performance is a description of the level of achievement of the implementation of an activity program or policy in realizing the goals, objectives, vision, and mission of the organization as outlined in the strategic planning of an organization. Performance is an act of process or a way of acting or performing organizational functions (Oxford Dictionary in Moeheriono (2014). Meanwhile, performance comes from the word "to perform" with several entries, namely:

a. Do, run, execute (to do or carry of a execute).

b. Fulfill or carry out an obligation of an intention or vow (to the discharge of fulfilling as a vow).

c. Carry out or perfect responsibility (to execute or complete and undertaking).

d. Doing something that is expected by a person or machine (to do what is expected of a person machine).

e. So it can be concluded from the above opinions that performance is the result of work performed by employees as work performance according to their responsibilities in the company or organization.

\section{Research Method}

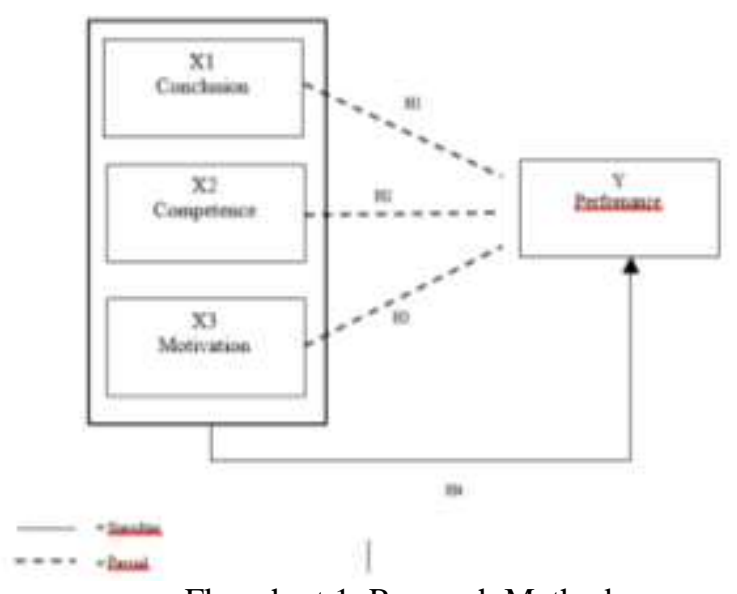

Flowchart 1. Research Method 


\subsection{Research Hypotheses}

Based on the research objectives, problem formulation, results of empirical studies and conceptual frameworks, the following hypothesis can be made:

a. It is assumed that Leadership Style, Competence and Motivation have a partially significant effect on the Employee Performance of Dinas Pengelolaan Bangunan dan Tanah Kota Surabaya.

b. It is assumed that leadership style, competence and motivation jointly influence the employee Performance Dinas Pengelolaan Bangunan dan Tanah Kota Surabaya.

\subsection{The type of research}

This type of research is field research, namely direct observation of the object under study to obtain relevant data. This research includes quantitative research.

\subsection{Population and Sample}

In this study, the population used was P.Employees who work in the Dinas Pengelolaan Bangunan dan Tanah Kota Surabaya, City Asset Management Unit, and based on the sampling results obtained, the researchers distributed 100 questionnaires from 132 employees who work in the Dinas Pengelolaan Bangunan dan Tanah Kota Surabaya, City Asset Management Unit.

\subsection{Types, Sources and Data Collection Techniques}

Data collection techniques used in this study are primary data and secondary data. Primary data is a source of research data obtained directly from the source namely employees of the Surabaya City Building and Land Management Service. To obtain this data, researchers used a questionnaire. The questionnaire is a data collection tool in the form of a written list of questions to obtain information from some respondents.

Secondary data is a source that does not directly provide data to data collectors, for example through other people or documents. To obtain secondary data, researchers used Library Research techniques through books, journals, the internet and other tools related to this research and study. Documentation, namely data collection is carried out by directly quoting data obtained from employees Performance Dinas Pengelolaan Bangunan dan Tanah Kota Surabaya.

\subsection{Data analysis technique}

1. Validity and Reliability Test

2. Multiple Linear Regression Test

$$
\begin{array}{ll} 
& \\
\mathrm{Y} & =\text { Interest in buying } \\
\mathrm{A} & =\text { Constant } \\
\mathrm{b} 1, \mathrm{~b} 2, \mathrm{~b} 3 & =\text { regression coefficient of variables X1, X2, X3 } \\
\mathrm{X} 1 & =\text { Leadership Style } \\
\mathrm{X} 2 & =\text { Competence } \\
\mathrm{X} 3 & =\text { Motivation } \\
\mathrm{e} & =\text { Error, Variable interference }
\end{array}
$$

\subsection{Test the Hypothesis}

\subsubsection{Partial Test (T-Test)}

This test aims to test whether the independent variables (Leadership Style, Competence and Motivation) on the dependent variable (Employee Performance) have a partial or separate effect.

\subsubsection{Test $\mathbf{F}$}

The $\mathrm{F}$ test is used to determine the significance level of the independent variables simultaneously on the dependent variable. 


\section{Results and Discussion}

Table 1. Respondent Character

\begin{tabular}{ccc}
\hline Gender & Total & Percent \\
\hline Male & 54 & $54 \%$ \\
Female & 46 & $46 \%$ \\
Total & 100 & $100 \%$ \\
\hline Education & Total & Percent \\
\hline SMA & 39 & $39 \%$ \\
Diploma & 29 & $29 \%$ \\
Sarjana & 32 & $32 \%$ \\
Total & 100 & $100 \%$ \\
\hline Ages & & \\
\hline$<20$ years old & 4 & $4 \%$ \\
21 - 25 years old & 28 & $28 \%$ \\
26 - 30 years old & 13 & $13 \%$ \\
31 - 35 years old & 15 & $15 \%$ \\
36 - 40 years old & 17 & $17 \%$ \\
$>41$ years old & 23 & $23 \%$ \\
Total & 100 & $100 \%$ \\
\hline
\end{tabular}

\subsection{Reliability and validity}

Table 2. Reliability Statistics

\begin{tabular}{cc}
\hline $\begin{array}{c}\text { Cronbach's } \\
\text { Alpha }\end{array}$ & N of Items \\
\hline, 937 & 17 \\
\hline
\end{tabular}

Based on the research results, it was obtained that the cronbanch alpha value was 0.937 , which means it was above the acceptable limit of 0.60 so that the research instrument for the relationship between variables showed good consistency and acceptable data.

\subsection{Multiple Analysis Test Results}

Table 2. Results of Multiple Regression Analysis Test

\begin{tabular}{cccc}
\hline Variable & Regression Coefficient & Counted & Sig. \\
\hline Constant & 0.983 & 1.240 & 0.003 \\
Leadeership Style (X1) & 0.240 & 3.396 & 0.001 \\
Competence (X2) & 0.239 & 3.152 & 0.002 \\
Motvation (X3) & 0.524 & 6.466 & 0.000 \\
F count & & 154,812 & \\
Significant & 0.00 & \\
R & 0.910 & \\
R2 & 0.829 & \\
Adjusted Rsquare & & 0.823 & \\
\hline
\end{tabular}

By entering the values obtained from the SPSS calculation above, multiple regression equations can be obtained, namely:

\subsection{Constant}

$$
\mathrm{Y}=0,983+0,240 \mathrm{X} 1+0,239 \mathrm{X} 2+0,524(\mathrm{X} 3)+\mathrm{e}
$$

Obtained a constant $\mathrm{Y}$ value of 0.983 , this shows the employee performance (Y) of 0.983 if it is assumed that leadership style (X1), competence (X2) and motivation (X3) are considered constant. 


\subsection{Leadership Style (X1)}

The leadership style regression coefficient (X1) is 0.240. This means that if the Employee Performance Dinas Pengelolaan Bangunan dan Tanah Kota Surabaya increases the influence of leadership style (X1), competence (X2) and motivation (X3) remain, it will increase employee performance (Y) by 0.240 units.

\subsection{Competence (X2)}

The competency regression coefficient (X2) is 0.239. This means that if the Employee Performance Dinas Pengelolaan Bangunan dan Tanah Kota Surabaya improves employee performance and other variables of leadership style (X1) remain, it will increase employee performance $(\mathrm{Y})$ by 0.239 units.

\subsection{Motivation (X3)}

Coefficient motivation regression (X3) of 0.524. This means that if the Employee Performance Dinas Pengelolaan Bangunan dan Tanah Kota Surabaya improves employee performance and other variables of leadership style (X1) remain constant, it will increase employee performance (Y) by 0.524 units.

\subsection{T-Test}

Table 3. Coefficientsa

\begin{tabular}{|c|c|c|c|c|}
\hline \multirow[t]{2}{*}{ Model } & \multicolumn{3}{|c|}{ Unstandardized CoefficientsStandardized Coefficients } & \multirow[t]{2}{*}{$\mathrm{t}$ Sig. } \\
\hline & $\mathrm{B}$ & Std. Error & Beta & \\
\hline (Constant) & , 983 &, 792 & & $1,240,003$ \\
\hline${ }_{1}$ Leadership_style (X1) &, 240 &, 071 & 232 & $3,396,001$ \\
\hline Competence (X2) & 239 &, 076 & 270 & $3,152,002$ \\
\hline Motivation (X3) & 524 &, 081 & 483 & $6,466,000$ \\
\hline
\end{tabular}

a. Dependent Variable: Performance (Y)

Based on the table above, it can be seen that the value of the leadership style variable (X1) is 3.396, the competency variable (X2) is 3.152, the motivation variable is (X3) is 6.466 .

1. Testing the influence of leadership style on employee performance.

The test results show that the value for the leadership style variable on employee performance shows a value $=3.396>$ of 1.983 with a significance of $0.001<0.05$ which means significant. Thus partially, leadership style has a positive and significant effect on the Employee Performance Performance Dinas Pengelolaan Bangunan dan Tanah Kota Surabayat ${ }_{\text {hitung }} t_{\text {hitung }} t_{\text {tabel }}$

2. Testing the influence of competence on employee performance.

The test results obtained from the value for the competency variable on employee performance showed a value $=3.152>$ of 1.983 with a significance of $0.001<0.05$, which means significant. Thus, partially, competence has a positive and significant effect on the Employee Performance Performance Dinas Pengelolaan Bangunan dan Tanah Kota Surabaya.

3. Testing the influence of motivation on employee performance.

The test results obtained from the value for the motivation variable on employee performance showed a value $=6.466>$ of 1.983 with a significance of $0.001<0.05$, which means significant. Thus, partial motivation has a positive and significant effect on the Employee Performance Performance Dinas Pengelolaan Bangunan dan Tanah Kota Surabaya.

\subsection{Test F}

Table 4. ANOVAa

\begin{tabular}{|c|c|c|c|c|}
\hline Model & Sum of Squa & sDfI & Lean Squa & Sig. \\
\hline Regression & 465,765 & 3 & 155,255 & $154,812,000 b$ \\
\hline 1 Residual & 96,275 & 96 & 1,003 & \\
\hline Total & 562,040 & 99 & & \\
\hline
\end{tabular}

a. Dependent Variable: KINERJA_PEGAWAI

b. Predictors: (Constant), MOTIVATION, LEADERSHIP_STYLE, COMPETENCY

Based on the table data above, it is known that it can be obtained $=154,812$ while the value is 2,696. Thus $154,812>2,696$. And a significant value of $0.000<0.05$, so it can be concluded that leadership style (X1), competence (X2), motivation (X3) simultaneously have a positive and significant effect on the Employee Performance Dinas Pengelolaan Bangunan dan Tanah Kota Surabaya (Y). 


\section{Discussion}

Based on the results of calculations using SPSS V.20, the results of these calculations are continued to the research discussion as follows:

a. The leadership style variable (X1) has a partially significant effect on the employee performance variable (Y). This is indicated by the magnitude of the significance value greater than 0.05 , which is equal to 3.396 . Based on these results, it can be concluded that leadership style has a significant influence on the employee Performance Dinas Pengelolaan Bangunan dan Tanah Kota Surabaya

b. The competency variable (X2) has a partially significant effect on employee performance (Y). This is indicated by the amount of significance value smaller than 0.05 , which is equal to 3.392 . Based on these results, it can be concluded that competence has a significant influence on the Employee Performance Dinas Pengelolaan Bangunan dan Tanah Kota Surabaya.

c. The motivation variable (X3) has a partially significant effect on employee performance (Y). This is indicated by the magnitude of the significance value is smaller than 0.05 , which is equal to 6.466 . Based on these results, it can be concluded that competence has a significant influence on the employee Performance Dinas Pengelolaan Bangunan dan Tanah Kota Surabaya.

d. The variable of leadership style (X1) competence (X2) and motivation (X3) has a significant effect simultaneously on the employee performance variable (Y). This is indicated by the magnitude of the significance value smaller than 0.05 , which is equal to 0.000 . Based on these results, it can be concluded that leadership style, competence and motivation together have a significant effect on the Employee Performance Dinas Pengelolaan Bangunan dan Tanah Kota Surabaya.

\section{Conclusions and Recommendations \\ 6.1 Conclusion}

Based on To obtain a comprehensive and integral understanding of the results of the research that has been carried out and the discussion described in the previous chapter, the following conclusions can be drawn:

a. There is a partially significant influence of leadership style on the performance of employees Performance Dinas Pengelolaan Bangunan dan Tanah Kota Surabaya. This is based on the results of the $t$ test of 3.396> 1.983 with a significance of $0.301>0.05$. This means that the better the leadership style applied by a leader can affect the performance Performance Dinas Pengelolaan Bangunan dan Tanah Kota Surabaya staff. $t_{\text {tabel }}$

b. There is a partially significant effect of competence on the performance Performance Dinas Pengelolaan Bangunan dan Tanah Kota Surabaya employees. This is based on the results of the $t$ test 3.152> from 1.983 with a significance of $0.039>0.05$, which means significant. Thus, partially, competence has a positive and significant effect on the Employee Performance Performance Dinas Pengelolaan Bangunan dan Tanah Kota Surabaya.t tabel

c. There is a partially significant effect of competence on the performance Performance Dinas Pengelolaan Bangunan dan Tanah Kota Surabaya employees. This is based on the $t$ test results of 6.466>1.983 with a significance of $0.039>0.05$, which means significant. Thus, partial motivation has a positive and significant effect on the Employee Performance Performance Dinas Pengelolaan Bangunan dan Tanah Kota Surabaya.

d. Together (simultaneously) there is an influence of leadership style, competence and motivation on the employee Performance Dinas Pengelolaan Bangunan dan Tanah Kota Surabaya. This is based on the results of the $f$ test of 154.812 and a significance level of 0.000 . This shows that the higher the value of leadership style, competence and motivation, the better the employee's performance.

Leadership style plays an important role in directing employees to do work to achieve agency goals. A leader can overcome complex problems by making wise decisions. A good leader always knows what his subordinates want and interacts both personally and professionally. Competence is the basis of ability in determining positions and tasks following their respective expertise based on formal education to improve existing competencies.

Motivation as a driving force for employee enthusiasm to carry out the work sincerely without any sense of pressure which can also harm the achievement of organizational goals. In this case, all variables affect employee performance.

Leadership style, competence and motivation have a significant influence on the performance of the employees Performance Dinas Pengelolaan Bangunan dan Tanah Kota Surabaya. This study shows that the variables contained in this study need to be considered to expect an increase in employee performance to achieve the goals and progress of the agency. 


\subsection{Suggestion}

a. For the leadership

It is recommended to pay attention to the needs and desires of employees when employees feel they have difficulties, always encouraging so that employees can be motivated to carry out their duties properly. Leaders can be creative, innovative and communicative in conditioning and assigning tasks to employees, following established procedures and regulations. Leaders can conditionally adjust their leadership style and leaders should be willing to formulate policies that can increase the competence of employees to achieve organizational goals.

b. For further researchers to be able to carry out deeper studies on the discussion of leadership style, competence, motivation in aspects and case studies in institutions that are more complex in terms of composition or employee background and are expected to select a wider population to get better results. With such a large population, the number of respondents will be many. One way to get better research results is to increase the significance level of the respondents.

\section{References}

basis van Hersey, Op P., and Johnson D. Management. 1996. "Leiderschapsstijlen Volgens Hersey \&amp; Blanchard Situationeel Leiderschap." Of Organisational Behavior Prentice Hall.

Dinas, Kinerja Pegawai, Pengelolaan Bangunan, Dan Tanah, and Zahra Wanisa. 2016. Kinerja Pegawai Dinas Pengelolaan Bangunan Dan Tanah Dalam Pelaksanaan Inventarisasi Aset Tanah Di Kota Surabaya Zahra Wanisa.

Hadari., Nawawi. 2014. Manajemen Sumber Daya Manusia Untuk Bisnis Yang Kompetitif. Yogyakarta: Gajah Mada University Fress.

Hamdu, Ghullam, and Lisa Agustina. 2011. "Pengaruh Motivasi Belajar Siswa Terhadap Pestasi Belajar Ipa Di Sekolah Dasar (Studi Kasus Terhadap Siswa Kelas IV SDN Tarumanagara Kecamatan Tawang Kota Tasikmalaya)." Jurnal Penelitian Pendidikan.

Handoyo, Eko, Ninuk Sholikhah Akhiroh, Thriwati Arsal, and Lailasari Ekaningsih. 2020. "Gender and Leadership in Indonesia: Insight the Achievements of the Female Mayor of Surabaya." Talent Development \& Excellence 12(2s):2315-27.

Harbani, Pasolong. 2013. Kepemimpinan Birokrasi. Bandung: CV.Alfabeta.

Harry Murti Veronika Agustini Srimulyani. 2013. "Pengaruh Motivasi Terhadap Kinerja Pegawai Dengan Variabel Pemediasi Kepuasaan Kerja Pada PDAM Kota Madiun - PDF Download Gratis." Retrieved March 25, 2021 (https://docplayer.info/45163687-Pengaruh-motivasi-terhadap-kinerja-pegawai-dengan-variabelpemediasi-kepuasaan-kerja-pada-pdam-kota-madiun.html).

Hasibuan. 2017. "Manajemen Sumber Daya Manusia." in Manajemen Sumber Daya Manusia.

Mangkunegara, AA. Anwar Prabu. 2014. Manajemen Sumber Daya Manusia. Bandung: PT. Remaja Rosdakarya.

Moeheriono. 2014. Pengukuran Kinerja Berbasis Kompetensi. Jakarta: Rajawali Pers.

Pasolong, Harbani. 2008. Teori Administrasi Publik. Bandung: Alfabeta.

Priansa, Donni Juni. 2017. "Manajemen Kinerja Kepegawaian Dalam Pengelolaan SDM Perusahaan." in Cetakan ke-1.

Rahadi, Dedi Rianto. 2010. “Manajemen Kinerja Sumber Daya Manusia.” Malang: Tunggal Mandiri Publishing. Rahim, W., J. Junaid, and J. Afa. 2016. "Hubungan Gaya Kepemimpinan Direktur Rumah Sakit Dengan Kinerja Pegawai Di Rumah Sakit Umum Daerah Kota Baubau Tahun 2016.” Jurnal Ilmiah Mahasiswa Kesehatan Masyarakat Unsyiah.

Sedarmayanti. 2013. Manajemen Sumber Daya Manusia, Bandung: Refika Aditama. Bandung: Refika Aditama. Spencer, A. 1993. "Managing Change in Organisations." Senior Nurse 13(3):18-22, 25. doi: 10.4324/9781315562933-10.

Umam, Khaerul. 2010. Perilaku Organisasi. Bandung: Pustaka Setia.

Veithzal RivaiVeithzal Rivai. 2013. "Manajemen Sumber Daya Manusia Untuk Perusahaan Dari Teori Ke Praktik." PT RajaGrafindo Persada, Jakarta. Retrieved March 25, 2021 (https://scholar.google.co.id/citations?user=m4JT6MwAAAAJ\&hl=en\#d=gs_md_cita$\mathrm{d} \& \mathrm{u}=\% 2 \mathrm{Fcitations} \% 3 \mathrm{Fview} \_o p \% 3 \mathrm{Dview} \_c i t a t i o n \% 26 \mathrm{hl} \% 3 \mathrm{Den} \% 26 \mathrm{user} \% 3 \mathrm{Dm} 4 \mathrm{JT} 6 \mathrm{MwAAAAJ} \% 26 \mathrm{citati}$ on_for_view\%3Dm4JT6MwAAAAJ\%3AqjMakFHDy7sC\%26tzom\%3D-420).

Wirawan. 2012. Evaluasi Teori, Model, Standar, Aplikasi Dan Profesi. Jakart: Rajawali Pers. 